\title{
A Framework for the Evaluation of the Feasibility of Public - Private Partnerships in Local Government in Serbia
}

\section{Sladjana Benkovic ${ }^{1}$, Nemanja Milanovic ${ }^{2}$, Milos Milosavljevic ${ }^{3}$}

\begin{abstract}
The adoption of the New Law for Local Government Financing is currently underway in a Serbian Parliament procedure. The goal of the new law is the creation of clear government regulations which will define the system of financing for local government entities. This will furthermore create an environment of stability and predictability with regard to revenue planning when preparing local government entities' budgets, as well as achieving a vertical balance when distributing revenues amongst various state levels. Additionally, these goals are reflected in the establishment of a system to increase the share of public investment in the total expenses of counties and cities, as well as in the vertical balance with regard to the distribution of revenue and jurisdiction at various state levels. In that sense, it is preferable to understand financial models such as public-private partnerships, which have still not, to an adequate degree, been adopted in Serbia, but one which could potentially contribute to the introduction of additional sources of local government financing. In order to better perceive the current capacities of this model of financing local government in Serbia, a study was conducted during the spring and summer of 2016, taking into account a sample of 150 examinees. The results of the study indicate very low human resource and technical capacities in local government with regard to realizing and comprehending the concept of public-private partnership.
\end{abstract}

Keywords: public-private partnership, local government financing, Serbia.

\footnotetext{
1 Sladjana Benkovic, Ph.D., Full Professor, University of Belgrade, Faculty of Organizational Sciences, Jove llica 154, 11000 Belgrade, Serbia, e-mail: benkovic.sladjana@fon.bg.ac.rs.

2 Nemanja Milanovic, Ph.D. Candidate, University of Belgrade, Faculty of Organizational Sciences, Jove Ilica 154, 11000 Belgrade, Serbia, e-mail: nemanja.milanovic@fon.bg.ac.rs.

3 Milos Milosavljevic, Ph.D., Assistant Professor, University of Belgrade, Faculty of Organizational Sciences, Jove Ilica 154, 11000 Belgrade, Serbia, e-mail: milos.milosavljevic@fon.bg.ac.rs.
} 


\section{INTRODUCTION}

Private capital investment in the public sector is a model of financing public administration by which numerous countries have tried to solve a wide spectrum of financially demanding public needs. This partnership is commonly referred to as a public-private partnership and is executed through a number of different models. The main focus of the public sector is on the infrastructure needed for the service distribution of the public utility, whereas the private sector takes the public utility as a given, and focuses on how to deliver the service as efficiently as possible, and make financial gains (Levitt \& Eriksson, 2016; Rufín \& Rivera-Santos, 2012).

The adoption of the New Law on Local Government Finance is currently underway in a Serbian Parliament procedure. The goal of the new law is the creation of clear government regulations which will define the system of financing for local government entities. This will furthermore create an environment of stability and predictability with regard to revenue planning when preparing local government entities' budgets, as well as achieving a vertical balance when distributing revenues amongst various state levels.

Such a method of financing for a local government represents a specific form of financing that is primarily suitable for the implementation of infrastructure and industrial projects (Espinosa \& Hernandez, 2016; Yang, Long, Cui, Zhu \& Chen, 2017). Many countries have begun to invite private parties to join longterm contractual agreements based on public-private partnerships to improve infrastructure procurement (Grimsey \& Lewis, 2002; Mouraviev \& Kakabadse, 2016). It represents a complex process in which an investor expects payback of the borrowed funds solely from the cash flows generated by an infrastructure project itself. Public-private partnerships are currently used in numerous countries as a tool for infrastructure procurement (Chou \& Pramudawardhani, 2015). This refers to both developed and developing countries (Tserng, Russell, Hsu \& Lin, 2011).

In 2016, the financing of infrastructure through public-private partnerships in local governments showed a tremendous decline worldwide (Word Bank, 2016). When we look at the level at which the public-private partnership appeared, successfully implemented projects through publicprivate partnerships at the national level are almost non-existent. At the local level, at the same time, projects occur in several different fields, through a) the provision of utility services, and b) the construction and reconstruction of public utility facilities.

The first group includes parking services, park maintenance, local public transport, garbage collection, waste transportation and disposal, the provision of market services, cleaning of public areas and the provision of cemetery 
services. The second category includes the construction and reconstruction of the following communal facilities: landfills, water distribution systems, wastewater treatment systems, district heating distribution systems, facilities for the provision of market services, and public garages.

This study aims to examine the main reasons why the concept of publicprivate partnership is not sufficiently employed in Serbian municipalities. The answer to this research question is backed by the results of empirical research conducted in Serbian local governments during the spring and summer of 2016. The results also point out the lack of entrepreneurial initiative in local governments which still strictly rely on budget funds.

The manuscript is organized as follows. Section 2 provides a theoretical background to local government and public-private partnerships, and develops the research hypotheses. Section 3 thoroughly examines the methodology of the study by explaining the main research instrument, sampling procedure and data processing. Section 4 displays the results of the study. Section 5 deals with the discussion of the results. Section 6 is reserved for concluding remarks.

\section{LITERATURE REVIEW}

Local government is "a locally-elected democratic statutory organization below the level of the state, province or region, providing public sector services to the populace within the area of its jurisdiction" (Bailey, 1999, p. 36). It is also referred to as the regulation and management of public affairs under local authorities' responsibility and legal frameworks (Council of Europe, 1985). The bodies of local governments are free to perform their functions in order to achieve the following goals (Vlatkovic, 1994):

- the right of citizens to participate in public affairs at the local level;

- the existence of bodies for decision making and allocating responsibilities for public affairs management;

- to perform public affairs in the interest of the local population within the limits of the law;

- to have sufficient assets to achieve these goals.

Serbian local governments generate around $74 \%$ of their revenues from grants, transfers and taxes, whose rates are under the control of central government. A detailed structure of local governments' revenues is presented below in Table 1 (Ministry of Finance, 2016). Transfer and other tax rates in Serbia are regulated by adopting the annual Law on Transfer Funds Distribution and Participation of Municipalities and City of Belgrade in Income Taxes (The Law on Local Government Finance, 2015). It is noteworthy to point out that Serbian local governments switched from zero-based budgeting to program budgeting in 2015 . 
Table 1. Distribution of Serbian local government revenues 2010-2016 (in millions RSD)

\begin{tabular}{lllllll}
\hline Year & $\begin{array}{l}\text { Total } \\
\text { revenues }\end{array}$ & Taxes & $\begin{array}{l}\text { Transfers and } \\
\text { grants }\end{array}$ & $\begin{array}{l}\text { Other } \\
\text { revenues }\end{array}$ & $\begin{array}{l}\text { Proceeds from } \\
\text { borrowing }\end{array}$ & $\begin{array}{l}\text { Privatization } \\
\text { proceeds }\end{array}$ \\
\hline 2010 & $193.040,50$ & $92.763,70$ & $34.656,20$ & $49.465,40$ & $15.721,90$ & 433,30 \\
2011 & $217.734,30$ & $110.498,20$ & $38.227,00$ & $47.196,90$ & $21.437,80$ & 372,80 \\
2012 & $249.490,00$ & $148.168,50$ & $41.713,20$ & $47.182,10$ & $12.106,40$ & 319,80 \\
2013 & $241.825,80$ & $142.088,10$ & $42.265,30$ & $48.887,60$ & $8.372,10$ & 212,80 \\
2014 & $234.192,00$ & $144.895,80$ & $42.997,40$ & $37.609,80$ & $8.002,40$ & 686,50 \\
2015 & $247.867,10$ & $150.196,90$ & $42.672,70$ & $44.578,30$ & $10.001,50$ & 417,80 \\
2016 & $276.109,20$ & $159.085,80$ & $46.271,00$ & $59.214,30$ & $11.225,50$ & 312,70 \\
\hline
\end{tabular}

Source: Ministry of Finance, Republic of Serbia (2017).

The ever growing need for new investments in traditionally ignored sectors, such as public transport, district heating, gas supply and solid waste management, has forced the local authorities in Serbia to establish publicprivate partnerships and to make room for the implementation of more innovative forms of providing utility services. Lee (2010) states that private sector involvement in financing and providing these services contributes to local governments' economic development. Furthermore, experience has shown that PPPs and their ability to supply private finance improves access, quality of service, operational efficiency, and tariff levels as dimensions of abovementioned sectors' performance (Marin, 2009). Such cooperation between the state and private entities aims to delegate the functions of the supply of water, gas, electricity, heat, utilities and maintenance of quality housing (Lydia \& Olga, 2013), providing numerous benefits to both public and private partner (Filushina, Kolyhaeva, Minaev, Dobrynina \& Merkuleva, 2015). At the same time, the transition from zero-based to program budgeting enables Serbian local governments to strictly monitor key performance indicators of state-owned utility companies and to compare their KPI's with KPI's of companies-partnerships between local government and private sector. Accordingly, the goals and indicators defined in program budgets can be used as a measurement system for the provided services' prices, quality and expenses. Besides the lack of Serbian local governments' agility and interest in partnering with the private sector, the core obstacle for attracting private capital in the utilities sector lies in the fact that the organizational form of public utility companies does not allow a capital increase from private partners (The Law on Public Enterprises, 2014; Vasiljevic, 2012).

Internal and external capacities were examined as critical success factors for the implementation of public private partnerships. Osei-Kyei and Chan 
(2015) find that risk allocation and sharing, strong private consortium, political support, community/public support and transparent procurement are the key critical success factors examined and explored in the extant publications on PPPs. On the other side, Li, Akintoye, Edwards and Hardcastle (2005) find that the most important factors for PPPs are effective search, project feasibility, government assurances, economic conditions and financial factors. To some extent, similar classification is given in Mota and Moreira (2015) who emphasize intrinsic (economic, legal and political environment), and extrinsic (economic viability, trust, risk management and procurement) success factors. Finally, Ng, Wong and Wong (2012) state that the right mixture of adequate technical, financial/economic, social, political, legal, and other factors can assure appropriate implementation of a PPP arrangement. Following the aforementioned, the study hypothesizes that:

Hypothesis 1: Public institutions and organizations have sufficient internal and external capacities for public-private partnerships.

Proponents of PPPs argue that they are an irreplaceable long-term solution due to the fact that the public sector alone cannot solve numerous issues in local governments (Benkovic, Krivokapic \& Milosavljevic, 2015). These partnerships need to be "carefully considered and well-articulated" (World Health Organization, 2015). This skepticism is fueled by PPP flaws such as the reduction of governments' ability to adapt to changing needs (Ross \& Yan, 2015) and high negotiation costs (Välilä, 2005). Following this argumentation, the authors developed a set of inquiries to explore the main reasons and rationale for the implementation of PPPs among Serbian local governments. Jacobson and OK Choi (2008) identified ten success factors that are presented and analyzed: specific plan/vision, commitment, open communication and trust, willingness to compromise/collaborate, respect, community outreach, political support, expert advice and review, risk awareness, and clear roles and responsibilities. However, the main reason for the implementation of PPPs is the lack of financial resources (Benkovic, Makojevic \& Jednak, 2013). Besides financial motives, the study aims to identify other drivers for implementing the concept of public-private partnership. Accordingly, the study hypothesizes that:

Hypothesis 2: Financial drivers are the most important for the implementation of public-private partnerships.

Ahadzi and Bowles (2004) claim that public sector organizations need organizational capabilities and technical capabilities for appropriate proposals on PPPs. The same 
authors indicate that the financial capabilities of the public sector are ranked lowest in influencing the procurement process. The implementation of public private partnerships requires high competencies of employees in local governments. Klijn and Teisman (2010) find that PPPs are not ideal when actors have difficulties in managing PPPs as they tend to "revert to traditional forms-by contracting out and by separating responsibilities". Following the stream of research, this study hypothesizes that:

Hypothesis 3: Public authorities have sufficient knowledge and skills for the implementation of public private partnerships.

\section{RESEARCH METHODS}

\section{Research instrument}

Data was collected using a questionnaire as the main research tool. The questionnaire was developed by the authors, based on a vast literature on critical success factors for the implementation of public private partnerships. Critical success factors are defined as "those few key areas of activity in which favorable results are absolutely necessary" for decision maker to reach their goals (Rockart, 1982, p. 76). Ever since the emergence of public private partnerships, the concept of CSFs has been employed by many researchers aiming to find the best ways for the implementation of public private partnerships (Liu, 2014).

The questionnaire used in the research consists of four parts. The first part addresses the demographic data and includes demographic data on examinees and examined local governments. The second part explored general attitudes, and internal and external capacities for the implementation of public-private partnerships. The third part focused on the examination of the main reasons for the implementation of public-private partnerships in the observed local governments. Finally, the fourth part analyzed the skills and knowledge of civil servants and political appointees related to publicprivate partnership implementation.

\section{Sampling procedure, sample characteristics and data processing}

The study examined the readiness of employees for the implementation of public-private partnerships in order to raise entrepreneurial awareness in the Serbian local governments. At the same time, this implies the strengthening of potential for local governments' financing, improving the quality of services at lower prices and rerouting of local governments' resources to other projects. The study was conducted on 150 examinees in ten Serbian local governments. 
As the total population of the local administration staff dealing with PPPs is unknown (to the best of authors' knowledge there is no global database of specialized clerks and managers), the sampling procedure was based on a "snowball" sampling technique (Biernacki \& Waldorf, 1981). This sampling relies on peer-to-peer recruitment of study participants and the formation of a referral chain (Bodin, et al., 2016). Although it can be a subject of various biases (see Avrachenkov, Neglia \& Tuholukova, 2016), the referral chain was actively controlled - particularly its initiation, progress and termination. Using the coded questionnaires, the number of referrals was controlled to limit the clustering within local administration with regards to their size. The distribution of examinees per the size of local administration is displayed in the Table 2.

Table 2. Distribution of examinees per local administration size

\begin{tabular}{ll}
\hline Size of local administration & Frequency \\
\hline Small $<10$ & 1 \\
Medium sized 11-50 & 44 \\
Large $51-250$ & 63 \\
Very large $>250$ & 38 \\
Total & 146 \\
Missing & 4 \\
Total & 150 \\
\hline
\end{tabular}

Data was captured by trained assistants and was entered and analyzed in the Statistical Package for Social Scientists program (SPSS) version 17.0. Quantitative data 27 was analyzed with demographic statistics: percentages, means and standard deviation. Interdependence of determinants (independent variables) and the attractiveness of public-private partnerships (dependent variable) were determined by correlation (Pearson moments two tailed correlation coefficient analysis) and multiple regression.

\section{ANALYSIS/STUDY/RESULTS}

Having analyzed these data, we discovered differences in internal capacities for the implementation of public-private partnerships, external capacities for the implementation of public-private partnerships in the Republic of Serbia, as well as rationalization for the implementation of public-private partnerships and disposable knowledge and skills for the implementation of public-private partnerships in the Republic of Serbia. 
Internal and external capacities for the implementation of publicprivate partnerships

Based on the previously elaborated body of knowledge, this study examined internal and external capacities for the implementation of public-private partnerships. Both of them were examined using a Likert-type scale (ranks 1-5). Internal capacities were examined through the following:

1) The suitability of PPP arrangements for local government.

2) Attitude of civil servants towards PPPs.

3) Attitude of political appointees (local government executives) towards PPPs.

4) General level of qualifications of employees.

5) General possibilities for the implementation of PPPs.

External capacities of local governments for the implementation of publicprivate partnerships were measured through the following inquires:

1) Favorability of legal procedures for the implementation of PPPs.

2) The amount of risk involved in PPP arrangements.

3) Unfavorable corruptive environment.

4) Inefficiency of central bodies.

5) Benevolence of political appointees towards the PPP model.

The results for internal and external capacities of local governments for the implementation of public-private partnerships are given in Table 3.

Table 3. Internal and external capacities for the implementation of PPPs

\begin{tabular}{lll}
\hline Internal capacities & Mean & Std. Deviation \\
\hline Suitability of PPP for local government & 3.50 & .923 \\
Attitude of civil servants & 2.21 & .719 \\
Attitude of political appointees & 2.60 & .861 \\
Employee qualifications & 2.43 & .812 \\
Possibilities for the implementation of PPPs & 2.86 & .858 \\
\hline External capacities & Mean & Std. Deviation \\
\hline Unfavorable legal procedures & 3.12 & .534 \\
High risk(s) & 3.27 & .510 \\
High level of corruption & 3.19 & .689 \\
Inefficient central bodies (Commission for PPP) & 3.56 & .744 \\
Incompatible political appointees & 3.47 & .830 \\
\hline
\end{tabular}

The results indicate that examinees found public-private partnerships to be an appropriate model for financing local government services. However, the general qualifications and expertise of employees is the main barrier. From the external point of view, the main limitations are systematic and driven from the inappropriate work of the central body for public-private 
partnerships which approves all projects of this kind. Considering the above mentioned findings, it can be stated that the first hypothesis is rejected.

\section{Rationale for public-private partnerships}

As the main rationales for implementation encompass both instrumental and normative aims (Brinkerhoff \& Brinkerhoff, 2011), the study examined 6 items of possible reasons for the implementation of public private partnerships. The results of descriptive statistics are presented in Table 4.

Table 4. The descriptive statistics for the main reasons for the implementation of PPPs

\begin{tabular}{lll}
\hline & Mean & Std. Deviation \\
\hline The lack of financial resources & 3.73 & .859 \\
The lack of service needed in the municipality & 3.19 & .808 \\
The urgency of service & 3.16 & .757 \\
High institutional support & 2.57 & .909 \\
The attractiveness of the project to potential investors & 3.42 & .806 \\
Private partner would cope with the risk better & 3.26 & .861 \\
\hline
\end{tabular}

As displayed in the table, the main reason for the implementation of public-private partnerships is the lack of financial resources (3.73), followed by the attractiveness of possible projects (3.42). However, examinees stated that institutional support needs to be improved if public-private partnerships are to be an important model for financing local projects, by which the second hypothesis is confirmed.

Table 5. Correlation matrix for particular reasons for the implementation of PPPs and the attractiveness of the model

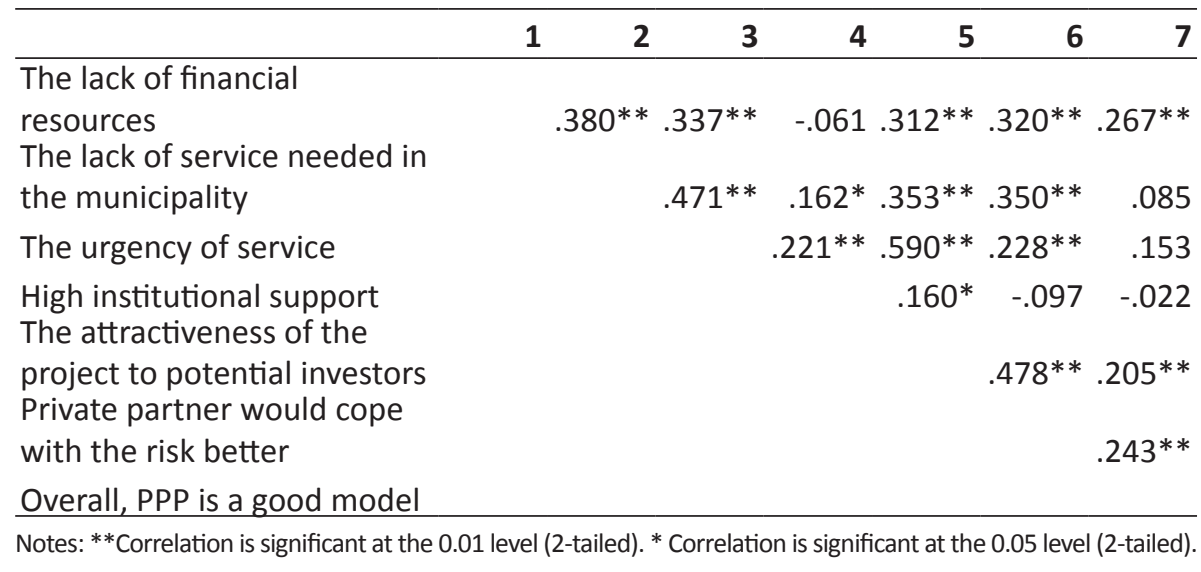


For the purpose of addressing hypothesis 2, a correlation and regression analysis was conducted. As shown in Table 5, significant correlation (with the attractiveness of public-private partnerships) was found between three particular reasons - a lack of financial resources, the attractiveness of projects offered to investors, and a private partner coping with the risks better.

Since the study found a strong positive correlation between rationales for the implementation of PPP variables and the attractiveness of publicprivate partnerships, the next step was the examination of the influence and intensity of variables seen as independent to the attractiveness of PPP (dependent variable). Results of the multiple regression analysis indicated that the research model predicted only $11.1 \%(R 2=.111)$ of the variability of the attractiveness of public-private partnerships, which is shown in Table 6 . As Durbin-Watson was $d=1.700$ (between two critical values $1.5<d<2.5$ ), it could be assumed that there is no first order linear autocorrelation in the multiple linear regression data. Collinearity was further examined with the variance inflation factor, and none of the variables had high VIF leading to the conclusion that the model did not express any multi-collinearity.

High significance of the F-test $(p<.01)$, indicates the existence of linear interdependence. Thus, the study results indicate that there was a linear relationship between the variables in the model. Beta expresses relative importance of each independent variable in standardized terms. Only one determinant was found to be a significant predictor of the attractiveness of public-private partnerships. Accordingly, the study results clearly indicate that the attractiveness depends on the fiscal considerations.

The results indicate that local governments lack employees with the appropriate knowledge in risk analysis (2.74), cost effectiveness (2.77) and value-for money studies (2.83). It is important to emphasize that the skills needed for traditional methods of procurement are highly developed, which could easily lead PPPs to traditional forms of service procurement. According to the described results, the third hypothesis is rejected. 
Table 6. Regression analysis for the attractiveness of PPP model

\begin{tabular}{|c|c|c|c|c|c|c|c|}
\hline \multirow[b]{2}{*}{ Model } & \multicolumn{2}{|c|}{$\begin{array}{l}\text { Unstandardized } \\
\text { Coefficients }\end{array}$} & \multirow{2}{*}{$\begin{array}{c}\text { Standardized } \\
\text { Coefficients } \\
\text { Beta } \\
\end{array}$} & \multirow[b]{2}{*}{ 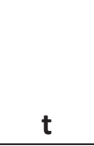 } & \multirow[b]{2}{*}{ Sig. } & \multicolumn{2}{|c|}{$\begin{array}{c}\text { Collinearity } \\
\text { Statistics }\end{array}$} \\
\hline & B & Std. Error & & & & Tolerance & VIF \\
\hline (Constant) & 1.998 & .453 & & 4.415 & .000 & & \\
\hline $\begin{array}{l}\text { The lack of financial } \\
\text { resources }\end{array}$ & .227 & .094 & .213 & 2.418 & .007 & .766 & 1.305 \\
\hline $\begin{array}{l}\text { The lack of service } \\
\text { needed in the } \\
\text { municipality }\end{array}$ & -.112 & .107 & -.099 & -1.054 & .294 & .669 & 1.494 \\
\hline $\begin{array}{l}\text { The urgency of } \\
\text { service }\end{array}$ & .078 & .127 & .064 & .613 & .541 & .541 & 1.849 \\
\hline $\begin{array}{l}\text { High institutional } \\
\text { support }\end{array}$ & -.019 & .085 & -.019 & -.224 & .823 & .871 & 1.148 \\
\hline $\begin{array}{l}\text { The attractiveness } \\
\text { of the project to } \\
\text { potential investors }\end{array}$ & .060 & .122 & .052 & .490 & .625 & .516 & 1.938 \\
\hline $\begin{array}{l}\text { Private partner } \\
\text { would cope with } \\
\text { the risk better }\end{array}$ & .182 & .101 & .170 & 1.799 & .074 & .666 & 1.501 \\
\hline
\end{tabular}

Note: R2=.111; Adj R2=.076, F=3.130 (Sig=.006); Durbin-Watson=1.700.

\section{Knowledge and skills for public-private partnerships}

For the purpose of addressing Hypothesis 3, this study examined the main competencies of local government employees. The results are displayed in Table 7.

Table 7. Knowledge and skills of local government employees required for the successful implementation of PPPs

\begin{tabular}{lll}
\hline & Mean & Std. Deviation \\
\hline Public procurements & 3.51 & .624 \\
Legal procedures & 3.34 & .580 \\
Value for money analysis & 2.83 & .752 \\
Risk analysis & 2.74 & .779 \\
Cost benefit analysis & 2.77 & .800 \\
Financial management & 2.84 & .803 \\
Project control & 2.97 & .675 \\
Contracting and negotiating & 3.01 & .642 \\
\hline
\end{tabular}




\section{DISCUSSION}

The aim of the study was to provide an answer as to why the concept of publicprivate partnership is not sufficiently employed in Serbian municipalities. Accordingly, we examined internal and internal factors that drive PPPs, the main reasons for the implementation and the knowledge and skills of public administration in handling PPPs. In a nutshell, public private partnerships are a suitable model for financial local infrastructure and delivery of public services, but local administration lacks expertise for the appropriate implementation of particular projects. Also, the most important determinants for any consideration of application of public-private partnerships are fiscal constraints and lack of funds. Finally, the most important skills that local administrations need are related to the legal issues (public procurements, legal procedures and contracting).

The main contribution of the paper is reflected in understanding the current environment for strengthening entrepreneurship in Serbian local governments, which implies improving the quality of provided services at lower prices and the rerouting of local governments' resources to projects which are out of the private sector's interest. However, local administrations need to improve their capacities (knowledge and skills) for the implementation of complex projects. Capacity building initiatives have already proven to be a solid tool for improvement in the public-private partnership area (Aijaz, 2010). Fewer financial, human, land and property resources under the control of local governments facilitate private initiatives and local economic development.

An additional contribution of this paper is the empirical proof that financial constraints are a fundamental driver for public-private partnerships. It should, however, be noted that resources saved by a government that does not finance the upfront investment are offset by giving up future revenue flows to the concessionaire (Engel, Fischer \& Galetovic, 2013). More than merely a financial issue, public-private partnerships carry substantial organization, strategy, management and policy implications (Roehrich, Lewis \& George, 2014).

\section{CONCLUSION}

In this study, we aimed to stress the significant potential of public-private partnerships for the financing and economic development of Serbian local governments. It is evident that local governments have both internal and external capacities needed for the successful implementation of publicprivate partnerships, but their employees' still lack the sufficient knowledge and skills necessary for this process. Therefore, intensive educational 
programs and training for the improvement of employees' competencies, skills and knowledge are suggested as one of the priorities for efficient local government development.

Besides permanent education and training of employees, significant effort must be put into communication and relationship management with citizens and private entities. Public and private sectors have to be understood as cooperative, so therefore collaborations must be considered when they are qualitatively different from both private and public activities, and superior to each on its own. The public-private partnership concept represents an established systematic approach of many governments and local self-governments around the world when it comes to financing public infrastructure. Over the past few years, municipalities in Serbia have made the first tentative steps towards the introduction of public-private partnerships, mainly in the utilities sector. The growing need for new investments in traditionally neglected sectors, such as public transport, district heating, gas supply and solid waste management, has forced the municipal authorities in Serbia to, little by little, establish public-private partnerships and open the door to more innovative forms of providing utility services.

The local authorities in Serbia are still in the early stages of the process of establishing the political, legal and administrative framework that would facilitate the development of public-private partnerships. However, improving the quality of provided services at lower prices, the rerouting of local governments' resources to projects which are out of the private sector's interest, and the permanent education and training of employees could considerably facilitate entrepreneurial orientation and the implementation of public-private partnerships in Serbian local governments.

\section{References}

Ahadzi, M., \& Bowles, G. (2004). Public-private partnerships and contract negotiations: An empirical study. Construction Management and economics, 22(9), 967-978.

Aijaz, R. (2010). Capacity building of municipal functionaries for good governance in Uttarakhand, India. Habitat International, 34(4), 386-391.

Avrachenkov, K., Neglia, G., \& Tuholukova, A. (2016) Subsampling for chainreferral methods. In S. Wittevrongel \& T. Phung-Duc (Eds.), Analytical and Stochastic Modelling Techniques and Applications (pp. 17-31). ASMTA 2016. Lecture Notes in Computer Science, 9845. Cham: Springer.

Bailey, S.J. (1999). Local Government Economics: Principles and Practice. Basingstoke: Palgrave Macmillan.

Benkovic, S., Krivokapic, J., \& Milosavljevic, M. (2015). Application of the public-private partnership organizational structure in the improvement 
of business operations of public sector enterprises in Serbia. Lex Localis, 13(3), 397.

Benkovic, S., Makojevic, N., \& Jednak, S. (2013). Possibilities for development of the electric power industry of Serbia through private source financing of small hydropower plants. Renewable Energy, 50, 1053-1059.

Biernacki, P., \& Waldorf, D. (1981). Snowball sampling: Problems and techniques of chain referral sampling. Sociological Methods \& Research, 10(2), 141-163.

Bodin, T., Johansson, G., Hemmingsson, T., Nylén, C., Kjellberg, K., Buström, B., \& Östergren, P.-O. (2016). S09-2 respondent-driven sampling in sampling hard-to-reach precarious workers. Occupational and Environmental Medicine, 73(Suppl 1), A109.1-A109.

Brinkerhoff, D.W., \& Brinkerhoff, J.M. (2011). Public-private partnerships: Perspectives on purposes, publicness, and good governance. Public Administration and Development, 31, 2-14.

Chou, J. S., \& Pramudawardhani, D. (2015). Cross-country comparisons of key drivers, critical success factors and risk allocation for public-private partnership projects. International Journal of Project Management, 33(5), 1136-1150.

Council of Europe. (1985). European Charter of Local Self-Government. European Treaty Series, 122.

Engel, E., Fischer, R., \& Galetovic, A. (2013). The basic public finance of publicprivate partnerships. Journal of the European Economic Association, 11(1), 83-111.

Espinosa, A., \& Hernandez, T. (2016). A comparison of public and private partnership models for urban commercial revitalization in Canada and Spain. The Canadian Geographer/Le Géographe Canadien, 60(1), 107-122.

Filushina, K.E., Kolyhaeva, J.A., Minaev, N.N., Dobrynina, O.I., \& Merkuleva, J.A. (2015). Regional models on managing the public-private partnership projects in housing and communal complex. Mediterranean Journal of Social Sciences, 6(3S5), 55.

Grimsey, D., \& Lewis, M.K. (2002). Evaluating the risks of public private partnerships for infrastructure projects. International Journal of Project Management, 20(2), 107-118

Jacobson, C., \& Ok Choi, S. (2008). Success factors: Public works and public-private partnerships. International Journal of Public Sector Management, 21(6), 637-657

Klijn, E. H., \& Teisman, G. R. (2003). Institutional and strategic barriers to public-private partnership: An analysis of Dutch cases. Public Money and Management, 23(3), 137-146.

Lee, S. (2010). Development of public private partnership (PPP) projects in the Chinese water sector. Water Resources Management, 24(9), 1925-1945.

Levitt, R.E., \& Eriksson, K. (2016). Developing a governance model for PPP infrastructure service delivery based on lessons from Eastern Australia. Journal of Organization Design, 5(1), 7. 
Li, B., Akintoye, A., Edwards, P.J., \& Hardcastle, C. (2005). Critical success factors for PPP/PFI projects in the UK construction industry. Construction Management and Economics, 23(5), 459-471.

Liu, J., Love, P.E., Smith, J., Regan, M., \& Davis, P.R. (2014). Life cycle critical success factors for public-private partnership infrastructure projects. Journal of Management in Engineering, 31(5), 1-7.

Lydia, O., \& Olga, Z. (2013). The potential of public-private partnership for solving housing and communal services. Analytic and Informative Journal, 126(6), 120-124.

Marin, P. (2009). Public-Private Partnerships for Urban Water Utilities: A Review of Experiences in Developing Countries. Washington DC: World Bank Publications.

Ministry of Finance, Republic of Serbia. (2017). Public Finance Bulletin No. 152. Retrieved from http://www.mfin.gov.rs/UserFiles/File/bilten\%20 javne\%20finansije/2017/ Bilten\%20152\%20ENG\%202007.pdf

Mouraviev, N., \& Kakabadse, N.K. (2016). Conceptualising public-private partnerships: A critical appraisal of approaches to meanings and forms. Society and Business Review, 11(2), 155-173.

Mota, J., \& Moreira, A.C. (2015).The importance of non-financial determinants on public-private partnerships in Europe. International Journal of Project Management, 33(7), 1563-1575.

Ng, S.T., Wong, Y.M., \& Wong, J.M. (2012). Factors influencing the success of PPP at feasibility stage-A tripartite comparison study in Hong Kong. Habitat International, 36(4), 423-432.

Osei-Kyei, R., \& Chan, A.P. (2015). Review of studies on the critical success factors for Public-Private Partnership (PPP) projects from 1990 to 2013. International Journal of Project Management, 33(6), 1335-1346.

Rockart, J.F. (1982). The Changing Role of the Information Systems Executive: A Critical Success Factors Perspective. Boston: Massachusetts Institute of Technology.

Roehrich, J.K., Lewis, M.A., \& George, G. (2014). Are public-private partnerships a healthy option? A systematic literature review. Social Science \& Medicine, 113, 110-119.

Ross, T.W., \& Yan, J. (2015). Comparing public-private partnerships and traditional public procurement: Efficiency vs. flexibility. Journal of Comparative Policy Analysis: Research and Practice, 17(5), 448-466.

Rufín, C., \& Rivera-Santos, M. (2012). Between commonweal and competition understanding the governance of public-private partnerships. Journal of Management, 38(5), 1634-1654.

The Law on Local Government Finance. (2015). Official Gazette of RS, No. 62/2006, 47/2011, 93/2012, 99/2013, 125/2014, and 95/2015 (Article 37).

The Law on Public Enterprises. (2014). Official Gazette of RS, No. 119/2012, 116/2013 and 44/2014.

Tserng, H.P., Russell, J.S., Hsu, C.W., \& Lin, C. (2011). Analyzing the role of national PPP units in promoting PPPs: Using new institutional 
economics and a case study. Journal of Construction Engineering and Management, 138(2), 242-249.

Välilä, T. (2005). How expensive are cost savings? On the economics of publicprivate partnerships. European Investment Bank Papers, 10(1), 94-119.

Vasiljević, D. (2012). Lokalni Ekonomski Razvoj - Zašto Su Jedne Opštine Dobitnici, A Druge Gubitnici Tranzicije. Beograd: PALGO Centar.

Vlatković, M. (1994). Lokalna Samouprava u Srbiji - Prilog Kritici Uređivanja i Ostvarivanja. Beograd: Stalna Konferencija Gradova i Opština.

World Bank. (2016). 2016 Private Participation in Infrastructure (PPI)-Annual Update. Retrieved from https://ppi.worldbank.org/ /media/GIAWB/ PPI/Documents/Global-Notes/2016-PPI-Update.pdf

World Health Organization. (2015). Public-Private Partnerships for Health. Retrieved from www.who.int

Yang, T., Long, R., Cui, X., Zhu, D., \& Chen, H. (2017). Application of the public-private partnership model to urban sewage treatment. Journal of Cleaner Production, 142, 1065-1074.

\begin{abstract}
Polish)
Przyjęcie nowej ustawy o finansowaniu samorzqdów lokalnych jest obecnie w toku procedury parlamentu serbskiego. Celem nowej ustawy jest stworzenie przejrzystych regulacji rzq̨dowych, które określq system finansowania dla jednostek samorzqdu terytorialnego, co dodatkowo stworzy warunki stabilności i przewidywalności w zakresie planowania dochodów przy przygotowywaniu budżetów jednostek samorzqdu terytorialnego, a także jako osiqgnięcie równowagi pionowej przy dystrybucji dochodów między różnymi poziomami państwowymi. Ponadto, cele te znajdujq odzwierciedlenie $w$ ustanowieniu systemowego zwiększenia udziału inwestycji publicznych w całkowitych wydatkach powiatów i miast, a także w równowadze pionowej w zakresie podziału dochodów i jurysdykcji na różnych poziomach państwowych. $W$ tym sensie lepiej jest zrozumieć modele finansowe, takie jak partnerstwa publiczno-prywatne, które jeszcze nie zostały w wystarczajqcym stopniu przyjęte w Serbii, ale które moga potencjalnie przyczynić się do znalezienia dodatkowych źródeł finansowania przez samorzqdy. Aby lepiej dostrzec obecne możliwości tego modelu finansowania samorzqdu lokalnego w Serbii, przeprowadzono badanie wiosna i latem 2016 r., Biorqc pod uwagę próbę 150 osób, wyniki badania wskazujq na bardzo niskie zasoby ludzkie i możliwości techniczne samorzqdu lokalnego w zakresie znajomości i zrozumienia koncepcji partnerstwa publiczno-prywatnego.
\end{abstract}

Słowa kluczowe: partnerstwo publiczno-prywatne, finansowanie samorzqdów terytorialnych, Serbia. 


\section{Biographical notes}

Slađana Benković - Ph.D., has been a full professor at the Faculty of Organizational Sciences in Belgrade since 2014 and has participated in numerous projects. During 2007/2009 she spent a period of time at the George Washington University, Washington D.C. as a research fellow. She is the President of the Management Board of the "Endowment of Milivoje Jovanović and Luka Ćelović", as well as a member of the Management Board of the "Endowment of Đoko Vlajković. . Her teaching and research fields are financial management with a research focus on project finance, modalities of financing the development projects of companies, technical evaluation of investment profitability and determination of corporate capital structure.

Nemanja Milanović - M.Sc., is currently employed as a teaching assistant at the University of Belgrade, Faculty of Organizational Sciences, Department of Financial Management and Accounting. His main fields of research interests are financial management, management accounting and startup funding models. He gained international professional experience through a number of international study and professional exchanges and research projects. He is a member of the European Finance Association and the Youth Committee of the National Petroleum Committee of Serbia - World Petroleum Council.

Miloš Milosavljević - Ph.D., is an assistant professor at the University of Belgrade, Faculty of Organizational Sciences. He teaches Financial Management and Management Accounting and has participated in numerous consulting projects in the field of financial management and controlling. He has authored or coauthored more than 60 articles and conference papers, text books and international monographs. 
